\title{
Legitimating Social Inequality: Political Elites, Ethnic Peddling and Dislocated Constituencies
}

\author{
Dr. Charles Che Fonchingong \\ Canterbury Christchurch University, School of Public Health, Midwifery and \\ Social Work, Canterbury, United Kingdom
}

doi: 10.19044/esj.2016.v12n26p163 URL:http://dx.doi.org/10.19044/esj.2016.v12n26p163

\begin{abstract}
Political cronyism has been flagged up as a trigger for state dysfunction in post-independence Africa, resulting in escalating social inequality. This paper lays out elite (mostly elderly) dislocation of political space; polarizing communities with constituents feeling distant from governmental machinery with constituency representation under siege. Using case studies, backed up with documentary analysis, framed in conjunction with the conceptual thinking of deliberative democracy; this study engages with the elements of dislocation. Constituency misrepresentation is laid out through a triangulation of case study material drawn from newspaper reports, discourses and counter narratives, amplified by process tracing and inferential analysis. Elite manipulation of political spaces exacerbates social inequality, creates fractured communities; undermines democratic mandate, social advancement and broad citizen consensus. From media coverage of glib slogans, elite pledge generic support for the regime in place whilst constituents are giving false expectations that seldom materialize into concrete development. There are no clear-cut manifestos that reflect the voices of constituents against bogus claims to state institutions with the political elite purportedly speaking on behalf of their constituents -'the people'. The ensuing inertia creates a false sense of representative governance as projects promised are rarely delivered. Slogans should usefully channel the development needs of constituents, permitting government to calibrate a robust development portfolio and citizen assemblies factored into policy design and service delivery. Developing a stakeholder approach and building the capability of social development professionals, in order to filter through pressing concerns with measurable outcomes, bolstering youth employment and fostering social protection would remove the lock jams in constituencies. Strategic spending in public services and essential infrastructure such as health, roads, transport, water, power supply and education are crucial in reducing inequality.
\end{abstract}


Keywords: Constituency, citizen assemblies, inequality, deliberative democracy, misrepresentation, political elite, infrastructure

\section{Introduction: Elite cronyism, factionalism and social inequality}

Africa is the second-most inequitable region in the world, after Latin America. Despite good economic forecasts, the paradox remains the deepening levels of economic inequality that accompany Africa's growth prospects (World Bank, 2016), with the gap between rich and poor extremely high (Oxfam 2016). According to the African Development Bank (2012), the surge in social inequality has not diminished over time in sub Saharan Africa (SSA). In 2010, six out of the 10 most unequal countries worldwide were in SSA. There are ever-increasing disparities between the rich and the poor within most of SSA, and the region remains home to 29 out of 32 of the least developed countries in the world (UNDP Africa Development Report 2012), with persistent poverty and grinding inequalities considerable challenges (Human Development Report 2015). If goal 10 of the sustainable development goals (SDGs), 2030 development agenda on reducing inequality within and among countries is to be achieved, then the root causes most be forensically identified and addressed. SSA countries are principally known for their high levels of economic inequality and poverty; with specific characteristics of vulnerabilities, yet what sustains these inequalities are largely overlooked (Ellis 2012; Thorbecke 2013, UNDP 2014). How do the political elite (chiefly elderly) account for these imbalances and how can the rising inequality be remedied? Arguably, the understanding of different sources of inequality is a prerequisite towards the implementation of policies that foster a sustained growth, thereby dismantling potential threats posed by constituency disengagement. The overall picture on African inequality is complex. 7 of the 10 most unequal countries in the world are in Africa, most of them in southern Africa, yet the number of extremely wealthy Africans is increasing and differences between urban and rural areas and across regions remain large (World Bank 2016, Oxfam 2016). A growth and inequality survey of households point to sharp inequality; based on monetary and non-monetary outcomes, disaggregated by regions in Cameroon (Fambon et al. 2014). Data from the National Institute of statistics and ECAM 4 (2014) indicates that $37.5 \%$ of the population is living on the edge and below the poverty threshold. From an estimated population of over 21.6 million inhabitants, over 8.1 million are trapped in rising poverty in 2014, up from 1.9 million in 2001 . The percentage of persons living in poverty between 2001 and 2014 is telling: $40.2 \%$ in $2001,39.9 \%$ in 2007 and $37.5 \%$ in 2014. 
Table I: Inequality in Africa Relative to Other Developing Economies

\begin{tabular}{lcc}
\hline Gini & Africa & Other Developing Countries \\
\hline Mean & 0.43 & 0.39 \\
Median & 0.41 & 0.38 \\
Ratio of incomes: & & \\
Top 20\% / Bottom 20\% & 10.18 & 8.91 \\
\hline Low-income & 0.42 & 0.39 \\
Lower-middle-income & 0.44 & 0.40 \\
Upper-middle income & 0.46 & 0.40 \\
\hline
\end{tabular}

Source: WIDER Inequality Database, 2014; World Development Indicators, 2014

The country Gini indexes range from 0.31 (Niger) to 0.63 for South Africa (World Bank 2016). Cameroon, like the majority of developing countries, is witnessing challenges linked to the persistence of poverty which eventually constitute a source of social conflict and vulnerability (Fambon et al. 2014: 1). A pressing social development priority is the need to address surging inequality and high levels of poverty. In consonance with the tenets of deliberative democracy and based on a triangulated documentary analysis of media coverage of glib slogans, masterminded by political elite, this paper lays down the problematic of constituency misrepresentation as a trigger for endemic inequality in Cameroon.

Despite noticeable efforts to liberalize political systems and establish democratic institutions in Africa, progress has stalled with wane commitment attributed to political elites (Gyimah-Boadi 2015). Elite machinations, neopatrimonial politics and patronage have been identified as a primary source for the development deficits in SSA (Fonchingong, C. 2005, Karinge 2013; Orock 2015). Equally, the problem of a democratic recession and move towards authoritarianism are sketched out (Diamond 2015). Other notable commentators have laid the charge plaguing Africa's democratic advancement marred by elite competition for the control of state power and access to material resources (Chabal and Daloz 1999, Daloz 2010, Gyimah-Boadi 2015; Nnoli 1998). However, traditional explanations for inequality are reviewed and found not to be compelling (Van de Walle 2009). Still, the exogenous western concepts of development that do not consider the specificity and historicity of the SSA societies seeking to promote their development has been advanced with elite groups blamed for constraining development (Maathai 2009). I argue that elite manipulation of political space deepens social inequality, rather than decrease it with citizens left behind in social development. Citizens are seemingly trapped as mere spectators rather than active participants in governance; the question of accountability and constituency representation is masked, making the task onerous for policy makers and social development practitioners. 


\section{Method and Context}

Based on a qualitative methodology of process tracing, case study and inferential analysis, this paper wrestles with the problematic of growing inequality legitimated through a politics of elite misrepresentation of constituencies in Cameroon. The key method of data collection hinges on qualitative and documentary analysis, augmented with a triangulation of newspaper reports representing the discourses and counter narratives. This method is interconnected with explorations of documents and material discussed through process tracing. Process tracing permits researchers to 'move beyond written sources, and ask probing theoretically driven questions of key participants in the events and processes of interest (Tansey 2007:771). The method of process tracing adds inferential leverage (Collier 2011). Careful description is a foundation of process tracing, a perspective emphasized by Mahoney (2010). Process tracing integrates discussions of causal-process observations, gives greater attention to description as a key contribution (Collier 2011). Process tracing is arguably the most important tool of causal inference in qualitative and case study research (George and Bennett 2005, Bennett and Elman 2006).

The descriptive component of process tracing begins not with observing change or sequence but rather with taking good snapshots at a series of specific moments (Collier 2011:824). Descriptive inference in process tracing focuses on finding and interpreting diagnostic evidence to address descriptive tasks (Mahoney 2010). Process tracing aims to obtain information about well defined and specific events and processes; not to draw a representative sample of a larger population of political actors that can be used as the basis to make generalisation about the full population, but to draw a sample that includes the most important political players that have participated in the political events being studied (Tansey 2007:766). In relation to evidence, George and Bennett (2005) aver it is necessary to critically assess and weigh the value of collected data, recognising the pitfalls that may limit the usefulness of such information along with its benefits. The case study and process tracing approaches are conceptualised in this paper as the correlation of evidential documents, discourses and occurrence, prevalence and elements of reaction and counter reaction by the political actors identified. The tests associated with process tracing can help a researcher establish that: (1) a specific event or process took place, (2) a different event or process occurred after the initial event or process, and (3) the former was a cause of the latter (Mahoney 2012:571). The glib slogans, claims and counter-claims masterminded by the political elite in Cameroon are instructive of how the people are distant and feel distanced from government.

If the Cameroon nation is to live to its noble ambition of building an emergent economy by 2035 as stipulated by President Paul Biya, then opening 
the political space to tap the voices of citizens and addressing pressing social development challenges constitutes a significant barometer of progress. I prosecute the argument that deliberative democracy is in reverse mode with escalating inequality resulting in the bifurcation of constituencies. The political elite use carefully worded messages of support to government purportedly on behalf of their constituents - 'the people' which legitimates social inequality. In redressing social inequality, this paper makes the case for a re-orientation of so-called 'people's call'. Instead, they should be deployed as a memorandum to remind government of its social development obligations, infrastructure development; unfulfilled electoral promises and other manifesto commitments. It also proposes that the political elite from all the ten regions should be more accountable through a constituency audit of political slogans and what it is meant to achieve. Such accountability will permit political elite to ensure the views of constituents are genuinely represented to national government and voices of citizens at grassroots level tapped. This approach will make it pointless for glib slogans purportedly written on behalf of 'the people'.

Constituencies are plagued by rising levels of poverty, unemployment, higher levels of economic deprivation and income inequality, jeopardising access to essential services. While economic prospects are getting better; this is yet to be translated in living conditions with pro-poor citizens growing exponentially whilst the political elite are flourishing through a politics of fractured constituencies. It is argued that if citizens are left behind, feeling let down by their representatives and do not have a stake in governance, this legitimates instead of de-legitimates inequality. The political elite employ the strategy of slogans to make 'false claims' on behalf of their constituents (the people). Such a strategy creates a semblance of masked representation, opening the flood gates for the fragmentation of constituencies. The political elite continue to plunder the benefits of economic growth that is disproportionately skewed in favour of the ruling elite. This paper has made the case that the bifurcation of constituencies is the end result, heightened by gross misrepresentation of constituency needs and pressing development concerns. Community priorities are misjudged and the elite legitimise inequality by projecting politically vested interests, they purport to stand for the concerns of their constituents.

Through carefully worded slogans and messages of support, no concrete proposals on social development challenges, reflecting the daily travails of citizens are proposed. Such actions disconnect with state institutions from citizenry; health care system, social security and essential infrastructure are in a state of disrepair, exacerbating social inequality. Framed within the context of ethnicity and divided societies, this paper concludes with some proposals on how to lessen the growing inequality; through putting in 
check the excesses of elite interventions that breed factionalism and cronyism. The actions and inactions of political elite project vested interests and engender the dislocation of constituencies, orchestrated to garner support for the political establishment. Presumably, the elite have taken centre stage of political space leading to the detachment of constituencies. From the slogans, it is inferred that the polarisation within Cameroonian society is triggered by the lack of social justice, inclusive policies and a real politic that remains unsustainable against the core principles of deliberative democracy. The end result of misrepresentation; creation of disaffected constituencies with citizens feeling far removed from governance and nurturing divided societies.

\section{Conceptual thinking: Political elite and deliberative democracy in divided societies}

Given the context of multiparty aggregative democracy in Africa, deliberation as argued by (Ani, 2013) goes beyond mere voting. It should be central to decision making and for a decision to be legitimate, it must be preceded by deliberation, not merely the aggregation of pre-existing fixed preferences. The propensity for excessive requisition of state resources in a logic of spoilage that Bayart (1993) characterised as the "politics of the belly", results in people distrusting the institutions and policies of the state and trusting more their ethno-regional political "big-men" (Daloz, 2005) are critical, the notion of deliberative democracy in reverse underpins the central thesis of this paper.

Conceptually, deliberative democracy (Bohman 1998), neopatrimonialism, political instrumentalization of disorder exemplified by Chabal and Daloz (1999) and quasi states (Jackson, 1987) are substantiated characterizations of the political elite and weak states that creates divided societies (Horowitz 1993), leading to national disintegration (Fonchingong C 2005), rather than constitutional democratic consolidation (GyimahBoadi,2015). Deliberative democracy hinges on 'the inclusion of all citizens in deliberation and the exclusion of extra-political or endogenous forms of influence, such as power, wealth, and pre-existing social inequalities' (Bohman, 1996 p. 36). The concept of political elite employed in this study is different from the usual understanding of elite as an upper or dominant class. In line with the definition adopted by elite theory (or elitism), in this article elite refers to a group that is smaller than a class, defined by the occupation of strategic positions granting access to resources of power in society, whether economic, political or symbolic (Higley and Burton 2006).

According to Higley and Burton (2006), elites occupy the upper echelon of organizations and powerful movements and thus are capable of influencing political life on a regular and substantial basis. This breeds authoritarianism and the unwillingness of the political elite to relinquish 
authoritarian control (Gyimah-Boadi 2015) is a harbinger for bifurcation and dislocation. Daloz (2010) aver that political elites seek legitimation by attaching great importance to paraphernalia of government and prestige goods to elicit deference from commoners. Whilst the logics of association and identity with an ethnic group can yield tangible benefits in terms of pressing government on social development concerns, the manipulation of ethnic identity and political systems by elite for personal aggrandisement is detrimental (Fonchingong, C. 2005). Horowitz (2014:7) observes that 'a severely divided society is one in which ascriptive cleavages are highly salient in politics (more salient than alternative cleavages such as social class), a few groups contend for power at the centre, and there is a history of interethnic antipathy'. This phenomenon is evident in Cameroon's political landscape where political elites use ethnic groupings to make claims and 'false' representations to create fractured and divided societies.

Deliberative democratic theory can enable us to rethink the relation between inclusion and moderation and, correspondingly, to reframe the debate over which kind of institutions are most appropriate for divided societies (O'Flynn 2007). From the theoretical literature, this paper stretches out the false sense of representation inherent in the usage of the word 'the people' with often 'bogus claims' that are advanced by the political elite on behalf of their constituency. Such tendencies and actions have destabilising effects of widening inequality; consequently, this invalidates the ethos of deliberative democracy; conceptualised by Bohman (1998) as inherently biased in favour of the interests of dominant groups. Deliberative democracy, broadly framed, is ... any one of a family of views according to which the public deliberation of free and equal citizens is the core of legitimate political decision making and self-government' (Bohman, 1998, p. 401). Proponents of deliberative democracy argue that deliberation should ideally be inclusive enough to involve all citizens affected by the laws and regulations decided through democratic processes; needs to be public enough not to allow ideology and other types of preconceptions that might 'distort' reason-giving to pass unnoticed (Bohman, 1996, Dryzek, 2005, 2009). Hence, people are unequal when they cannot to the same degree make themselves heard and influence the course of discussions (Holdo 2014). The focus is to create spaces protected from de-legitimization strategies of the dominant where the dominated can develop counter discourses (Olson 2011 p. 537).

\section{Peddling Ethnicity: 'People's call' and glib slogans}

Political slogans, fashioned as a weapon of political 'survival' by the political elite from the ten regions of Cameroon creates split allegiances amongst constituents. Motions of support and elite machinations through carefully worded messages, written on behalf of constituents requesting the 
president to run for elections are illustrative. This raises fundamental questions on citizenship voices (what role do the populace play in politics, apart from casting votes); respect for the constitution, role of political parties in selecting candidates and accountability for such a mandate, and fundamentally, the whole question of contextual democracy hijacked by the political elite. This begs the question: are the messages of support and allegiance to the leader genuine or politically motivated? If they are genuine, then why are the authors not listed in most of these motions; what process of consultation is organised and what level of veracity and legitimacy are attached to these pledges or statements of support.

Ethnicity and political tribalism have been identified as important determinants in democratic transformation in Africa with varying consequences and outcomes (Lonsdale, 1994, Chabal and Daloz 1999), with elections in African countries nothing more than ethnic "censuses" (Horowitz 1985, 319-324), as voters cast their vote along ethnic lines and against policy preferences. Thus, ethnic appeals can be useful to politicians because constituencies are usually dominated by an ethnic group, and "the appeal of common ethnic ties can generate unified support where other issues would be divisive" (Bates 1974:470). The fissures of intensifying structural particularities at more localized levels meet the intentional deployment of factionalization by the state (Fonchingong, C. 2005).

Such divisions play into the hands of the elite whose vested interests take precedence, thereby widening inequality as the voices of ordinary citizens are seemingly masked. Whilst motions of support may not necessarily be counter-productive as they constitute a plebiscite of government action and policy, it would be worthwhile if they identify constituency problems, and plausible suggestions on how government can redress identified challenges. Such motions should be signed and written up in prior consultation and authorisation. Economic growth is yet to translate into infrastructure, social development and betterment of living conditions of African citizens.

Capitalizing on ethnicity constitutes a faux pas as the political elite are blamed for fostering non-inclusion, thereby legitimising inequality. Kohli (1993) argues that ethnicity often serves as the pole of mobilization; in a divided society, ethnic affiliations provide a sense of security, a source of trust, certainty, reciprocal help, and protection against neglect of one's interests by others perceived as the outsiders and strangers (Horowitz 1985). O'Flynn (2007:733) argued that deliberative democracy 'requires us to shift away from an elite-driven process towards a process in which the decisions that result can, in a meaningful sense, be understood as expressions of the will of the people - where 'the people' is construed, not narrowly in terms of ethnic leaders and those they purport to represent, but in terms of the full diversity of views and positions in society'. 
Let us consider this motion of support (glib slogan) from the speaker of the national assembly (Cameroon legislature), purportedly representing the views of the political elite and constituents from the Far-North region of Cameroon.

“...Les forces vives, chefs traditionnels, élites politiques du Rassemblement Démocratique du Peuple Camerounais (RDPC) -- parti au pouvoir depuis 33 ans --, ressortissants des trois Régions du Grand-Nord (Adamaoua, Nord et Extrême-Nord), appellent le Président Paul Biya à briguer un nouveau mandat en 2018. Ils étaient réunis vendredi 29 janvier 2016 à Yaoundé sous la conduite du très honorable Cavaye Yeguie Djibril, président de l'Assemblée Nationale. A l'ordre du jour de cette rencontre, la signature d'une motion de soutien et de déférence à l'endroit du Chef de l'Etat, le président Paul Biya, «pour ses efforts constants déployés depuis son accession à la magistrature suprême, pour promouvoir la paix, la démocratie et la justice sociale au Cameroun, et singulièrement pour sa sollicitude et la haute confiance qu'il a toujours témoigné aux fils et filles du septentrion», relate la CRTV, la radio nationale, dans son journal parlé de $20 \mathrm{~h} 00$. Afin de lui permettre de poursuivre l'œuvre de construction ainsi entamée, les participants à cette réunion lui ont lancé un appel: «Nous, forces vives, présidents de sections, chefs traditionnels et élites politiques $d u$ Rassemblement Démocratique du Peuple Camerounais des trois régions de l'Extrême-Nord, du Nord et de l'Adamaoua, réunis ce jour à Yaoundé, après avoir examiné les situations sociopolitique, économique, humanitaire et sécuritaire de nos régions, adressons à son excellence monsieur Paul Biya, Président de la République, Chef de l'Etat, chef des armées et président national du Rassemblement Démocratique du Peuple Camerounais, la motion de soutien lui réaffirmant notre soutien total dans la croisade qu'il mène contre le terrorisme et l'insécurité en général, afin de préserver l'intégrité du territoire national. Nous lui exprimons notre profonde gratitude pour toutes ses attentions et celles de son illustre épouse Mme Chantal Biya, en faveur des victimes des attaques terroristes qui endeuillent nos familles. A cet effet, pour lui permettre de poursuivre l'œuvre de construction nationale qu'il mène déjà avec tant de bonheur, de sagesse et d'expérience pour un Cameroun en paix, uni, démocratique, prospère, émergent et fort, lui demandons de bien vouloir se porter candidat à la prochaine élection présidentielle...».

From a triangulated perspective, it is worthwhile to consider the next motion of support issued as an ironic rebuttal of the negativity on glib slogans. The current minister of Higher Education, who doubles as National Communication Secretary of the Cameroon's People's Democratic Movement (CPDM) makes the 'constitutional, natural' case for slogans backing the president to run for 2018 presidential elections and challenges other parties to 
put forward their own arguments and candidates. The minister's statements and counter proposition are unpicked by the media:

«Au Cameroun, Jacques Fame Ndongo n'est pas seulement le ministre de l'Enseignement Supérieur (MINESUP). Il est aussi le secrétaire national à la Communication du RDPC, le parti au pouvoir. C'est cette dernière casquette qu'il a arborée le 9 février 2016 au moment d'accorder une interview à Cameroon Tribune, le quotidien gouvernemental. Les grandes lignes de cet entretien qui porte sur les multiples motions de soutien à Paul Biya, relatives à la prochaine élection présidentielle, sont reprises dans les colonnes de La Nouvelle Expression (LNE) du 10 février: "Si quelqu'un dit que moi je ne veux pas du président Paul Biya, je veux plutôt $Y$, qu'il $s$ 'organise pour que Y arrive dans les conditions d'éligibilité absolues lorsque les élections viendront», affirme sur un ton ironique Fame Ndongo. De l'avis de l'ancien ministre de la Communication, les militants du RDPC sont libres d'inviter leur champion à briguer un nouveau mandat. Les militants d'autres formations politiques doivent en faire autant: "Maintenant, que les autres se présentent aussi. Que des motions de soutien viennent des autres en disant, au lieu du président de la République nous voulons $X$. Nous attendons, nous sommes tout oüe et ceux-là ne seront pas inquiétés puisque la démocratie est là grâce au Président de la République Paul Biya», lance-t-il, comme un défis aux partis politiques d'opposition. Il dit d'ailleurs ne pas comprendre les critiques contre les militants de son parti: "Pourquoi voulez-vous brider ou anesthésier les opinions? ...Je ne comprends pas cette résurgence de la pensée unique», ajoute-t-il. LNE analyse aussi que le MINESUP a administré une leçon aux leaders de l'opposition: «Le Marketing politique est une permanence. Ceux qui ne s'en souviennent qu'à un mois de l'élection sénatoriale, municipale, présidentielle vont découvrir la réalité des faits. C'est qu'ils arrivent peut être trop tard sur un terrain déjà quadrillé, ratissé par un parti politique, qui lui est en permanence en campagne. L'Homme politique doit en permanence être en phase avec ses militants, avec ses partisans et avec ceux qui le soutiennent».

From the perspective of individually orchestrated memorandum, senators representing the centre region (current administrative seat of government) issued this terse slogan, meant to pledge unflinching support for the President:

“Après l'appel des élites de la région du Sud la semaine dernière, c'est le tour des sénateurs du Centre à inviter Paul Biya à se représenter à la prochaine échéance présidentielle prévue en 2018. Les sénateurs ont fait entendre leur voix hier Mercredi 20 janvier 2016 lors de la cérémonie de présentation des vœux de nouvel an au président du Sénat, Marcel Niat Njifenji. "Nous les sénateurs du Centre, nous pensons qu'il est très important de faire savoir au peuple les réalisations du Président Paul Biya. Il est en train 
de réaliser plusieurs projets dans notre pays. C'est pour cette raison que nous pensons qu'il doit continuer dans ce même sens pour atteindre son projet de l'émergence», a indiqué le sénateur Bell Luc René sur les ondes de la radio nationale ce 21 janvier. Le président du Senat qui a suivi le message des sénateurs du Centre, a promis le transmettre à son destinataire, Paul Biya ».

The statement below gleaned from the comments section of the tabloid newspaper - public reaction to the senators' slogan is instructive. It raises a fundamental question on the voices of citizens in the crafting of these memoranda of support and how this aligns with the epistemic tenets of deliberative, consensual, accountable and representative democracy. The perception of the political elite as a nepotistic and recycled clique, seemingly out of touch and seeking to protect its ill gotten wealth and positions of privilege is embedded in the statement below by a concerned citizen. Such glib slogans do not capture ordinary people's daily travails of soaring food prices, rising fuel costs, dismal health system and infrastructure like roads in a state of disrepair.

"Quitte là hein!!! comme on dit au village. De quel peuple du parles? Le petit peuple connait vos bêtises là? Les élites du Sud: ministres et DG Les Sénateurs du centres: Elus du RDCP, anciens maires ou députés, voire ancien ministres ou délégués du gouvernement. Donc les gens sont assis sur leurs milliards dans leurs villas à Yaoundé gagnés grâce au système de corruption généralisé. Ils décrètent à partir de Yaoundé que LE PEUPLE veut Biya à vie. Mais de quel peuple parle-t-on? Le peuple de milliardaires/voleurs/bandits à col blancs/pilleurs qui ont le cul entre Nkodengui et le comité central RDCP? ou bien le peule, de bayam sellam, de benskineur, de paysans, d'étudiants, de petits fonctionnaires, de femme ou foyers qui tous les matins de démènent comme de beaux diables pour survivre à la maladie, au manque d'eau potable, aux accouchements difficile, aux routes parmi les plus dangereuses du monde, à l'insécurité, au Sida, au palu, dont l'espérance de vie moyenne est de 50 ans?? Mais de quel peuple parle-ton? Tout ça c'est une tragicomédie bien orchestrée par les gens du pouvoir pour garder leur bien jusqu'à la fin des temps. Quitte à sacrifier le pays tout entier. Tant qu'ils ont le ventre plein.....Donc arrête de dire des conneries $d u$ genre : "Ce monsieur a tout donne, et le peuple demande encore plus"

This glib slogan underneath from the Littoral region, purportedly signed by a CPDM senator and deposited with the Governor of the region is telling. Apart from affirming support for the president to run in the forthcoming 2018 presidential elections, the signatory signals that it is the right approach that the incumbent president should not only contest, but should be declared winner of the upcoming election. Further, the senator provides a string of arguments to solidify his position. The president is portrayed as the only competent person to revitalize the party, overhaul its 
operational machinery, and ensure the implementation of key projects, extrapolated from media coverage:

"Des militants du Rassemblement Démocratique $d u$ Peuple Camerounais (RDPC), parti au pouvoir depuis 33 ans, arborant le pagne du parti, ont manifesté leur joie et leur souhait à l'idée de revoir à la Présidentielle 2018 leur président national non seulement en tant que candidat mais aussi et surtout vainqueur de l'élection. C'était mardi 26janvier 2016, à l'esplanade des services du gouverneur de la région du Littoral, auprès duquel ils ont déposé une motion de soutien. Sous l'impulsion du sénateur Thomas Tobbo Eyoum, membre $d u$ bureau politique et coordonnateur des activités du RDPC dans le Wouri, "des compatriotes ont réitéré leur détermination de voir le Chef de l'Etat, Son Excellence Paul Biya de nouveau aux rênes de la Nation en 2018», indique le quotidien La Nouvelle Expression dans son édition en kiosque mercredi 27 janvier. Thomas Tobbo Eyoum a exprimé son souhait en ces termes: «nous réaffirmons notre soutien à Paul Biya. L'homme politique», soutenant que le parti au pouvoir est le parti dominant au pays, apprend-on. Selon un de ses collaborateurs, «les grandes décisions qui seront prises concernent tout le monde. Je pense notamment à l'élection du président national qui est notre candidat naturel. Il y aura certainement lieu de réajuster quelques-unes de nos structures, compte tenu de la situation de certains de nos camarades, aussi bien du bureau politique que du comité central. Je pense également que les textes de base seront retouchés en vue de rendre le parti beaucoup plus dynamique. En amont, nous allons assister à une refondation de notre parti, afin que le RDPC en sorte revigoré pour continuer de servir les populations $\gg$.

Further to the glib slogans and memoranda of support referred above, there have been a string of prepared slogans from the political elite nationally requesting the national President of the CPDM party; in power since 1982 to seek another mandate in the impending (2018) presidential elections. The motions of support evidenced above raises fundamental questions on deliberative democracy: it is not clear when and how the constituents were involved in the deliberation and drafting of these motions of support. Further, the tendency is for the document to be relayed by a single signatory purportedly on behalf of other signatories. Thirdly, the memoranda from the speaker of the Assembly (Cameroon legislature) purportedly claimed to have mobilised citizens of the Far North region, yet, it is surprising there is no much detail on governments' efforts to quell the Boko Haram insurgency that has wreaked havoc and impacted on livelihoods in several northern constituencies, the birth place of the speaker. More than that, motions of support should reflect the local reality; utilized to galvanise constituents through collective and holistic local decision making to enable the government contain the threats posed by Boko Haram. Social development issues such as youth 
unemployment, job creation, migration, security and other concerns impacting on livelihoods require a stakeholder approach not captured in the glib slogans.

Interestingly, there are missed opportunities in the deployment of motions of support. Such statements can serve as a platform to flag up essential worries of constituents; such misrepresentation is captured in the counter reaction of a concerned citizen embedded above. Dryzek (2010:324) argues that if the individual is to be represented in anything like his or her entirety, all the discourses to which he or she subscribes generally merit representation in the forum. Further, that audience may itself be fractured in its commitments, and open to persuasion as to which of its commitments it ought to invoke. The legitimacy of African political elites derives from their ability to nourish the clientele on which their power rests. It is therefore imperative for them to exploit governmental resources for patrimonial purposes (Chabal and Daloz, 1999).

\section{Constituency detachment and peripheral involvement}

What emerges from the motions of support cited above is the dislocation of the constituency as its interests and pressing concerns are misrepresented. Such tendencies hold the destabilising potential, making the constituents feeling detached and peripherally involved. Given the unbalanced distribution of resources among various ethnic groupings, the elite use their constituency as a stepping stone. Thus, ethnicity is used a weapon to whip up ethnic sentiments and by so doing, jostle for positioning to draw down on often ill defined state resources and investment budgets allocated to the regions.

As a corollary, in its 2013 report, the African Progress Panel led by Kofi Annan, the former UN secretary general, reiterated: "After a decade of strong growth, several of Africa's resource-rich countries remain at the bottom of the international league-table for human development. Others register some of the world's largest inequalities in wealth and in well being, as captured by indicators such as life expectancy and education". Overall, the main aim of ethnic groups is to mobilize to exert pressure on political leaders to allocate rents and benefits to advance their collective interests (Young 2002). I have argued elsewhere that the Cameroon nation thrives on a dicey patchwork of national unity and integration that have become nebulous concepts with the political elite occupying centre stage of the discourses and ideologies on regionalism, orchestrated by the phenomenal search for political inclusion (Fonchingong C. 2005). Such actions result in the misrepresentation of constituents and widen inequality rather than lessening it. The documentary evidence and inferential analysis point to a politics of patronage and plundering of public funds that could have been re-channelled for infrastructure development. In narrowing the inequality gap as evident in elite manipulation of political space, the training and deployment of social workers 
and other social development practitioners in conducting robust baseline assessments, uncovering core needs, providing tailored solutions and targeted assistance is required for social policy design. Such an approach will mitigate the blockage and misrepresentation that citizens are subjected to by elite occupation and manoeuvring of political space.

\section{Misrepresentation of constituency concerns}

In levelling up social development thereby decreasing inequality, the case is made for citizens to feel connected to the state by recognising that their contribution and input counts and that in return they can expect basic provision of services from the state such as in health, infrastructure, education and social security. The creation of citizens' councils, forums, and assemblies at constituency level can help in filtering the concerns of ordinary citizens. Calibrated social Policy with huge priority placed on infrastructure development, revamp of health and social services, context-specific education tailored to the development needs of the country, social security policy and protection for the vulnerable and the elderly in particular. Inclusive economic policy modelled on partnerships with business and private sector to drive opportunities for employment and inclusive economic progress.

Erratic development support (one-off packages of support and sporadic help, aimed to garner votes and galvanise the electorate, mostly around the period of key elections - parliamentary and presidential (Fonchingong $\mathrm{C}$. 2005) is a noticeable feature of elite misrepresentation of their constituencies. Democratic constitutions have done little to restrain African presidents and political elites from wanton displays of impunity (Gyimah-Boadi 2015:104). More than that, the unclear manifestos; false hope and unfulfilled development promises further splinter communities. The misrepresentation of constituency levels up with Chabal \& Daloz (1999, p. 37) who aver that power within African states is often exercised "between big men, or patrons, and their constituent communities." However, this study makes the case that the power interplay with the constituency is slanted in favour of the elite thereby widening inequality.

The greatest challenge to representative democracy seems to be inequality, as participants are not materially or socially equal; neither do they have the same levels of deliberative capacity. Thus, unless measures are taken, these inequalities could be very significant in determining the outcome of deliberation (Ani 2013), enabling meaningful interactions between the political elite and their respective constituencies. The ethnic character of the state and rent-seeking elites is captured by Jackson (1987), in his concept of 'quasi states' in post-colonial Africa: The state is more a political or primordial-favouring political arrangement than a public-regarding realm. Government is less an agency to provide political goods such as law, order 
security; justice or welfare and more a fountain of privilege, wealth and power for small elite who control it . . . Many governments are incapable of enforcing their writ throughout their territory. In more than a few countries . . . some regions have escaped from national control ... [and the states] are fairly loose patchworks of plural allegiances and identities somewhat reminiscent of medieval Europe (Jackson 1987, pp. 527-28). Devolving down governance and effective decentralisation are options that can be considered for citizen engagement and participation.

\section{Devolving down governance and filtering citizen concerns}

The creation of citizens' councils can enable a filtering through of the development concerns and pressing needs of communities, without the reliance on political elite who misrepresent such concerns to suit their vested political and economic interests. The citizens' councils can also assist the state to drive development through co-designing policies and participation in regulatory frameworks to bench mark progress and to mitigate poverty and inequality in communities. Although, it is generally agreed that the best way to increase stability in divided societies is to create democratic institutions that enable conflicting groups to share power, there is much less agreement when it comes to deciding what those institutions should actually look like in practice (O’Flynn 2007).

Wider government consultation on the way decisions and policies are made to even out inequality would foster good governance, one that is trusted by the citizens. This participative governance model that people believe in could dampen the strangling influence of the elite and minimise the use of manipulative and opportunistic political slogans. Tackling elite disconnection from the constituency requires a mix of policies. Elite activities and representations should be publicised, scrutinised and audited. In serious cases of breach of constitutional and legal obligations, citizens' assemblies can pass a vote of no confidence which should be open to investigation and in extreme cases; the constituents can exercise the power of recall (annulling the right to represent the constituency). More than that, wider consultations should be pursued in government policy elaboration, implementation and review, enabling citizens concerns to be filtered through. The massive failure by government to provide equitable social development is associated to the disengagement of constituents in decision making.

Precisely, the masses have been continuously burdened by the excesses of a few people (elites) in their quest to consolidate and sustain power (Mbeki 2009, Maathai 2009). If deliberative democracy is to provide meaningful guidance for deeply divided societies, it must therefore take questions of institutional design extremely seriously, no matter how difficult these questions prove in practice (O'Flynn 2007:744). In reducing surging 
inequality, the economic prospects of the region have to be translated in uplifting the living conditions of citizens and greater investment in social development and essential infrastructure. Conversely, it is likely that the elites will use the reforms, brought in by the so-called transition to democracy, to secure both renewed legitimacy and access to the new assets that the liberalisation of the continent's economies makes available (Chabal and Daloz 1999).

\section{De-accelerating Inequality}

Reversing the surging levels of inequality hinges on how well ethnicity is downplayed and detoxified through legislative accountability and effective collaboration between political elite and constituents. Responsive governance requires the elite to advocate and bring to the fore the problems faced in their respective constituencies. This simply compounds a politics of inertia, where the preservation of an image of political stability secured through the regime's highly visible practice of seeming to involve as many actors as possible in matters of policy and decision-making means that few decisions are actually made (Fonchingong, C. 2005:376). Nevertheless, the very weakness and inefficiency of the state has been profitable to African elites. The development of political machines and the consolidation of clientelistic networks within the formal political apparatus have been enormously advantageous (Chabal and Daloz, 1999).

In order to break the grip of the African elites on political power, Mbeki (2009), suggests that building institutions that increase collaboration among communities; bridging cultural and linguistic divides; combating the ideology of tribalism and neo-tribalism used by political elites to divide and marginalize the masses; and strengthening communities as a means of creating accountable states, will address the deficits in development. Broad-based participation is also advanced as a possibility to enhance the accountability of decision-makers to domestic constituencies (Hickey and Mohan 2008), this 'elicit greater commitment to equitable and efficient development policies' (Booth 2005:1).

A stakeholder approach and the creation of citizen assemblies can mitigate the ambiguity surrounding elite involvement in the ethnicisation of politics. Citizen's forums can also serve as a microscope for scrutiny of government actions and tracking of manifesto commitments, downplaying the 'middlemen' role of the elite that is jeopardising developmental efforts and holding back the constituency. The problem of inequality is conceptualised by deliberative democrats - namely in terms of unequal deliberative capacities, failure to enforce the principle of equal consideration and biased norms of discourse (Holdo 2014). The severity of the current economic crisis in Africa is unlikely to favour the institutionalisation of the state. Political elites, bereft 
of the means of their patrimonial legitimacy, urgently seek the resources that the informalisation of politics might generate. Such heightened competition is apt to bring about greater disorder; if not violence (Chabal and Daloz 1999).The manipulation of political space by the political elite leaves little room for accountability to openly filter through the pressing needs of constituencies. Crucially important is the training and deployment of social development practitioners and social workers in conducting core assessments, build on the capacity and capability of constituents whilst feeding through key concerns into policy design and implementation. Increasing investments in health, education and small-scale agriculture are realistic ways of reducing inequality, yet having leaders who listen to their communities is crucial. Listening to citizens is vital to ensure wise investments and creating an enabling environment and a safe civic space for citizens and governments to work together to solve these critical governance challenges are preconditions for effective public investments to tackle inequality (Oxfam 2016:22).

\section{Conclusion}

Using qualitative and documentary analysis, process tracing and inferential analysis framed on the tenets of deliberative democracy, this paper has wrestled with social inequality legitimated through elite misrepresentation of constituents. I have argued that the political elite (mainly the elderly) detract the state from fulfilling its social development agenda leaving constituents feeling detached. This paper has affirmed that elite constitute an impediment to meaningful development; they use constituents as a stepping stone for political entitlement, and in the process, they derail government initiatives, creating competing legitimacies and leaving constituents disaffected. This culminates in ethnic peddling, an obstruction of government efforts in fulfilling its social development agenda and the delivery vital public services. For purporting to speak on behalf of their constituents -'the people' through glib slogans, the elite legitimate inequality, consequently jeopardizing constituency representation, a responsibility they are saddled with, the actuality being constituents feeling voiceless and disenchanted. The case is made for the creation and recognition of citizen assemblies to permit government to calibrate a holistic development portfolio that incorporates a stakeholder approach and accountability in decision making. This will address the manoeuvres by self seeking elite; promote meaningful interactions with constituents, largely cut off from debates and consultations. In reducing inequality, citizen assemblies would permit a better articulation of social development policy centred on pressing concerns such as tackling poverty and bolstering youth employment. Greater investment in social infrastructure such as health, water, roads, and power and energy supplies is vital. In driving these changes, a constituency audit of development needs, the training and 
deployment of social workers and social development professionals is crucially important. A stakeholder approach and policies inclined to build sustainable growth will lessen the manipulation of political space by the elite and cater for rising inequality, leaving behind stunted, discordant and fractured constituencies.

\section{References:}

Ani, E.I. (2013). Africa and the prospects of deliberative democracy, South African Journal of Philosophy, 32:3, 207-219, DOI: 10.1080/02580136.2013.837650

Bates, R. (1974). Ethnic competition and modernization in contemporary Africa. Comparative Political Studies 6(4):457-484.

Bayart, J-F. (1993). The State in Africa: The Politics of the Belly, Longman, London

Bennett, A. and Elman, C. (2006). 'Recent Developments in Case Study Methods'. Annual Review of Political Science 9:455-76

Bohman, J. (1996). Public Deliberation: Pluralism, Complexity and Democracy. Cambridge, MA: MIT Press.

Bohman, J. (1998). 'Survey article: The coming of age of deliberative democracy', Journal of Political Philosophy, 6 (4), 400-25.

Booth, D. (2005). Missing links in the politics of development: Learning from the PRSP experiment. ODI Working Paper No. 256. London: Overseas Development Institute.

Cameroon-Info.Net (2016). Cameroun - Présidentielle 2018/Fame Ndongo: «Si quelqu'un dit que moi je ne veux pas du Président Paul Biya, je veux plutôt Y, qu'il s'organise pour que $\mathrm{Y}$ arrive», retrieved at: http://www.camerooninfo.net/stories/0,70990, @,cameroun-presidentielle-2018-fame-ndongolaquo-si-quelqu-un-dit-que-moi-je-ne-ve.html Cameroon-Info.Net (2016). Cameroun - Présidentielle 2018: Les sénateurs de la région du Centre appellent Paul Biya à se porter candidat, retrieved at: http://www.cameroon-info.net/stories/0,70501,@,cameroun-presidentielle2018-les-senateurs-de-la-region-du-centre-appellent-paul.html Cameroon-Info.Net (2016). Cameroun - Présidentielle 2018: Sous la houlette de Cavaye Yeguie Djibril, les élites politiques et traditionnelles des Régions du grand-Nord invitent Paul Biya à se porter candidat, retrieved at : http://www.cameroon-info.net/stories/0,70651, @,cameroun-presidentielle2018-sous-la-houlette-de-cavaye-yeguie-djibril-les-elite.html

Cameroon-Info.Net (2016). Cameroun - Présidentielles 2018: Les militants RDPC du Wouri, sous la conduite du sénateur Thomas Tobbo Eyoum, supplient Paul Biya de se présenter, retrieved at : http://www.camerooninfo.net/stories/0,70598, @,cameroun-presidentielles-2018-les-militantsrdpc-du-wouri-sous-la-conduite-du-se.html 
Chabal, P. and Daloz, J-P. (1999). Africa works: Disorder as political instrument. Bloomington: Indiana University Press

Collier, D. (2011). Understanding process tracing, Political Science and Politics 44 (4) : 823-30

Daloz, J-P. (2005). "Nigeria: trust your patron, not the institutions", Comparative Sociology, Vol. 4 Nos 1/2, pp. 155-74

Daloz, J-P. (2010). How political representatives earn legitimacy: a symbolic approach, International Social Science Journal, UNESCO, Vol.196, pp.285296

Dryzek, J. (2005). 'Deliberative democracy in divided Societies: Alternatives to agonism and analgesia', Political Theory, 33 (2), 218-42.

Dryzek, J. (2009). 'Democratization as deliberative capacity building', Comparative Political Studies, 46 (4), 1379-1402.

Dryzek, J. (2010). Rhetoric in democracy: A systemic appreciation, Political Theory, Vol. 38, No. 3 (June 2010), pp. 319-339

Ellis, F. (2012). 'We are all poor here': economic difference, social divisiveness and targeting cash transfers in sub-Saharan Africa, Journal of Development Studies, 48(2), 201-214.

Fambon, S. McKay, A. Timnou, J-P. Kouakep, O-S. Dzossa, A. \& Tchakoute, R. (2014). Growth, poverty, and inequality: The case study of Cameroon, WIDER Working Paper 2014/154, retrieved at: https://www.wider.unu.edu/sites/default/files/wp2014-154.pdf

Fonchingong, C. (2005). Exploring the politics of identity and ethnicity in state reconstruction in Cameroon, Social Identities, Vol. 11, No. 4, July 2005, pp. $363-/ 380$

George, A.L. and Bennett, A. (2005). Case studies and theory development in the social sciences, Cambridge, Mass: MIT Press

Gyimah-Boadi, E. (2015). Africa's waning democratic commitment, Journal of Democracy, 16(1):101-13

Hickey, S. and Mohan, G. (2008). 'The politics of establishing pro-poor accountability: What can poverty reduction strategies achieve?' Review of International Political Economy 15(2): 234-58.

Higley, J. and Burton, M. (2006). Elite foundations of liberal democracy. Lanham: Roman and Littlefield Publishers.

Horowitz, D. (1985). Ethnic groups in conflict. Berkeley and Los Angeles: University of California Press.

Horowitz, D. (2014). Ethnic power sharing: Three big problems, Journal of Democracy Volume 25, Number 2 April 2014, pp.5-20

Human Development Report (2015). Work for human development, retrieved at: http://hdr.undp.org/sites/default/files/2015_human_development_report.pdf 
Jackson, R. (1987). Quasi-states, dual regimes, and neoclassical theory: International jurisprudence and the Third World, International Organisation, 41(4), 519-49.

Karinge, S. (2013). The elite factor in sub-Saharan Africa's development:

The urgency in bridging disparity, Journal of Developing Societies 29, 4 (2013): 435-455

Kohli, A. (1993). Democracy amidst economic orthodoxy: Trends in developing countries. Third World Quarterly 14(4):671-689.

Lonsdale, J.(1994). Moral ethnicity and political tribalism. In: Inventions and Boundaries: Historical and Anthropological Approaches to the Study of Ethnicity and Nationalism, edited by P. Kaarsholm and J. Hultin. Occasional Paper 11. Roskilde: Department of International Development Studies, Roskilde University.

Maathai, W. (2009). The challenge for Africa. NY: Pantheon.

Mahoney, J. (2010). 'After KKV: The new methodology of qualitative research' World Politics 62(1): 120-47

Mahoney, J. (2012). The logic of process tracing tests in the social sciences, Sociological Methods \& Research 41(4): 570-597

Mbeki, M. (2009). Architects of poverty: Why Africa's capitalism needs changing. Johannesburg: Pan Macmillan/Picador Africa.

National Institute of Statistics, Cameroon, (2014). Cameroun - Bien-être: En $2014,37,5 \%$ de la population vivait en dessous du seuil de pauvreté selon un rapport de INS, Le nombre de pauvre est par ailleurs passe de1,9 million en 2001 a 8,1 millions en 2014 ,

retrieved at: http://www.cameroon-info.net/stories/0,71556, @,camerounbien-etre-en-2014-37-5-de-la-population-vivait-nbsp-en-dessous-duseuil.html

Nnoli, O. Ed. (1998). Ethnic conflicts in Africa. Nottingham: CODESRIA.

O'Flynn I. (2007). Review article: Divided societies and deliberative democracy, British Journal of Political Science, Vol. 37, No. 4 (Oct., 2007), pp. 731-751

Olson, K. (2011). 'Legitimate speech and hegemonic idiom: The limits of deliberative democracy in the diversity of its voices', Political Studies, 59 (3), 527-46.

Orock, R. (2015). Elites, culture and power: The moral politics of 'development' in Cameroon, Anthropological Quarterly, 88(2), 533-568

Oxfam (2016). The time is now: Building a human economy for Africa, Oxfam briefing paper, 10 May 2016, retrieved at: http://policypractice.oxfam.org.uk/publications/the-time-is-now-building-a-humaneconomy-for-africa-608510 
Tansey, O. (2007). Process tracing and elite interviewing: A case for nonprobability sampling, Political Science and Politics, 40(4): 765-772

Thorbecke, E. (2013). The interrelationship linking growth, inequality and poverty in Sub-Saharan Africa, Journal of African Economies, 22(suppl 1), i15-i48.

United Nations Development Programme (UNDP) (2012). Africa human development report 2012: Towards a food secure future. New York: UNDP. UNDP (2014). Human Development Report (2014). Sustaining human progress: reducing vulnerabilities and building resilience, United Nations Development Programme, New York.

Van de Walle, N. (2009). The institutional origins of inequality in sub-Saharan Africa. Annual Review of Political Science. 2009, Vol. 12 Issue 1, p. 307-327 World Bank (2016). Poverty in a rising Africa, Africa Poverty Report, retrieved at: http://www.worldbank.org/en/region/afr/publication/povertyrising-africa-poverty-report

Young, C. (2002). Ethnicity and Politics in Africa. Boston: Boston University African Studies Center. 